\title{
Spatial and temporal dynamics of growth of woody plant species (birch and willows) on the foreland of a retreating glacier in southern Iceland
}

\author{
Haley E. Synan, Mikael A. Melfi and Lawrence H. Tanner ${ }^{*}$ (D)
}

\begin{abstract}
Background: The forelands of retreating glaciers are invaluable natural laboratories in which to explore the processes of primary succession. Numerous studies have been conducted on foreland chronosequences to identify temporal and spatial trends of the successional communities. This study focused on the spatio-temporal distribution of three woody plant species on the foreland of a retreating glacier in southern Iceland where historical observations provide precise age control of the moraines. To evaluate colonization and successional trends, we examined which species increase in abundance with time and tested the role of proximity to a seed source in colonization. Additionally, we quantified the rate at which biomass carbon is added to the landscape.

Results: The density of stems of Betula pubescens increases with moraine age across the foreland chronosequence while the density of stems of both Salix lanata and Salix phylicifolia decreases. We found low statistical significance to the relationship between the density of $B$. pubescens and distance from a forested ridge nor did we find a relationship between the lengths of the stems and the moraine ages. Woody biomass increased fastest during early successional stages and reached a maximum of $28.5 \mathrm{~g} \mathrm{C} \mathrm{m}^{-2}$ on the oldest moraine.

Conclusions: Early colonization of moraines was controlled by environmental filters which favored both Salix species. Colonization by B. pubescens followed as environmental factors, e.g., favorable soil properties, improved. We found no conclusive evidence that proximity to a potential source of $B$. pubescens propagules was a significant factor in controlling colonization. The assumption that the abundance of individuals increased with time through later successional stages proved valid for B. pubescens, but not for either species of Salix. These findings are consistent with the classical spatial successional model of community homogenization. Thus, general successional processes at the landscape scale control the temporal dynamics of individual species.
\end{abstract}

Keywords: Glacial foreland, Chronosequence, Primary succession, Spatial distribution, Aboveground biomass, Iceland

\section{Introduction}

Modern climate change has resulted in disproportionate warming at higher latitudes (IPCC 2014) and has the potential to impact ecological processes in arctic and subarctic environments in significantly measurable ways (Starfield and Chapin III 1996; Jägerbrand et al. 2012). One particular

\footnotetext{
*Correspondence: tannerlh@lemoyne.edu

Department of Biological and Environmental Sciences, Le Moyne College, Syracuse, New York 13214, USA
}

\section{Springer Open}

consequence of anthropogenic warming is the near-global impact on the mass balance of glaciers, which are now mostly in recession (IPCC 2019). The land surfaces exposed in front of many retreating glaciers, whether temperate or high latitude, constitute forelands with a maximum age corresponding to the local maximum advance during the Little Ice Age. The ages of different surfaces within such sequences may be constrained by recessional moraines of known or estimated ages, and therefore these surfaces constitute

(c) The Author(s). 2021 Open Access This article is licensed under a Creative Commons Attribution 4.0 International License, which permits use, sharing, adaptation, distribution and reproduction in any medium or format, as long as you give appropriate credit to the original author(s) and the source, provide a link to the Creative Commons licence, and indicate if changes were made. The images or other third party material in this article are included in the article's Creative Commons licence, unless indicated otherwise in a credit line to the material. If material is not included in the article's Creative Commons licence and your intended use is not permitted by statutory regulation or exceeds the permitted use, you will need to obtain permission directly from the copyright holder. To view a copy of this licence, visit http://creativecommons.org/licenses/by/4.0/. 
chronosequences on which rates of various ecological processes can be measured (Vreeken 1975).

The formation of these forelands has created exceptional opportunities to examine the rates and drivers of ecological processes during primary succession. Forelands exposed by the retreat of glaciers following the conclusion of the Little Ice Age have long been considered optimal settings for the study of rates and processes of landscape modification through floral colonization and pedogenesis (see review in Matthews 1992). As described by Fickert $(2017,2020)$, glacial forelands are indeed the ideal settings to investigate a number of aspects of succession, including the rate of colonization, the linearity (or nonlinearity) of colonization trends, the effects of interspecies competition in driving community composition, and the importance of local site conditions in determining both colonization order and later community diversity.

Most early studies documenting changes in community composition during primary succession in periglacial settings were conducted in Scandinavian Europe and North America on the forelands of temperate alpine glaciers (Butters 1914; Cooper 1916, 1931; Lüdi 1921, 1958; Negri 1934, 1936; Fægri 1933; Friedel 1934, 1937, 1938); far fewer studies have been conducted in arctic or subarctic settings, with the notable exception of studies of the glaciers on Svalbard (Liestøl 1988; Dowdeswell 1995; Liengen and Olsen 1997; Lefauconnier et al. 1999; Liengen 1999; Hodkinson et al. 2003). Nonetheless, the earlier studies remain useful as the differences in succession between temperate and high arctic glacial systems mainly involve differences in the species involved and the rates of change (Jones and Henry 2003).

In addition to community composition, numerous successional studies have examined the spatial distribution of the community constituents and how they change temporally. Years of research on the processes controlling spatial distribution has resulted in the development of three separate models of spatial succession (wellreviewed in Cutler et al. 2008), each predicting similar early stages dominated by stochastic processes during colonization (Yarranton and Morrison 1974; Matthews and Whittaker 1987; Matthews 1992; del Moral 1998, 1999) and patchy growth through positive interactions, mainly facilitation (Yarranton and Morrison 1974; Bertness and Callaway 1994; Cutler et al. 2008; Garibotti et al. 2011). The models differ in their predictions of later stage processes and outcomes, however. In the classical model, succession proceeds unidirectionally through growth and coalescence of patches, which increases facilitation and eliminates competing species, resulting in increased homogeneity (Yarranton and Morrison 1974; Holdaway and Sparrow 2006). The patch $d y$ namics model predicts that mature ecosystems will be in a constant state of flux as disturbances from internal or external forces create openings which revert to the pioneer stage (Holling 1992; Wu and Loucks 1995). The result is an ecosystem comprised of patches of various ages and at various stages of succession. In the geoecological model, the mature stage displays patch differentiation based primarily on heterogeneity in the physical environment, such as topography, soil depth, or moisture gradients, with consequent biotic responses that ameliorate adverse conditions (Matthews 1992; Bertness and Callaway 1994; Tirado and Pugnaire 2005).

Nearly all outlet glaciers of the large ice caps in Iceland are currently in recession, with many having retreated over $1 \mathrm{~km}$ in the last century (Sigurðsson 2005) leaving exposed forelands. These forelands comprise fresh surfaces of ice-contact and outwash deposits now subject to floral colonization and pedogenesis on chronosequences with maximum durations of over 100 years. The Skaftafellsj kull in southern Iceland started retreating in 1890 at the conclusion of the Little Ice Age. A nearby ridge, Skaftafellsheiði, that overlooks the glacier was covered by birch forest during this most recent glaciation, and so potentially served as a source of Betula pubescens seeds for colonization of the newly exposed land. Previous studies have documented that vegetative cover and soil development increases dramatically with distance from the current location of the glacial, which is a proxy for time (Vilmundardóttir et al. 2015). Glausen and Tanner (2019) studied successional changes in community structure and determined that both species density and species richness increased from early to middle stages but decreased in later stages as the vegetative cover increased, the latter changes largely through the increase of bryophytes. Those results suggested that succession proceeds in this location by the classical model, producing late-stage homogenization. Building on the earlier work, we studied the temporal and spatial trends of three woody species to investigate their individual responses from early colonization through later successional stages. Specifically, we tested changes in the abundance and distribution of B. pubescens and two Salix species over time to test how these trends conform to the classical model of succession. Furthermore, we investigated the importance of proximity to a propagule source in colonization of $B$. pubescens. As a secondary objective, we gathered data on biomass (above- and belowground) accumulation by these species.

\section{Methods}

\section{Location and setting}

The Skaftafellsj kull is one of many outlet glaciers of the Vatnajökull ice cap (Fig. 1). Many of these glaciers reached their Little Ice Age maximum extent in the late nineteenth century and receded consistently through the 


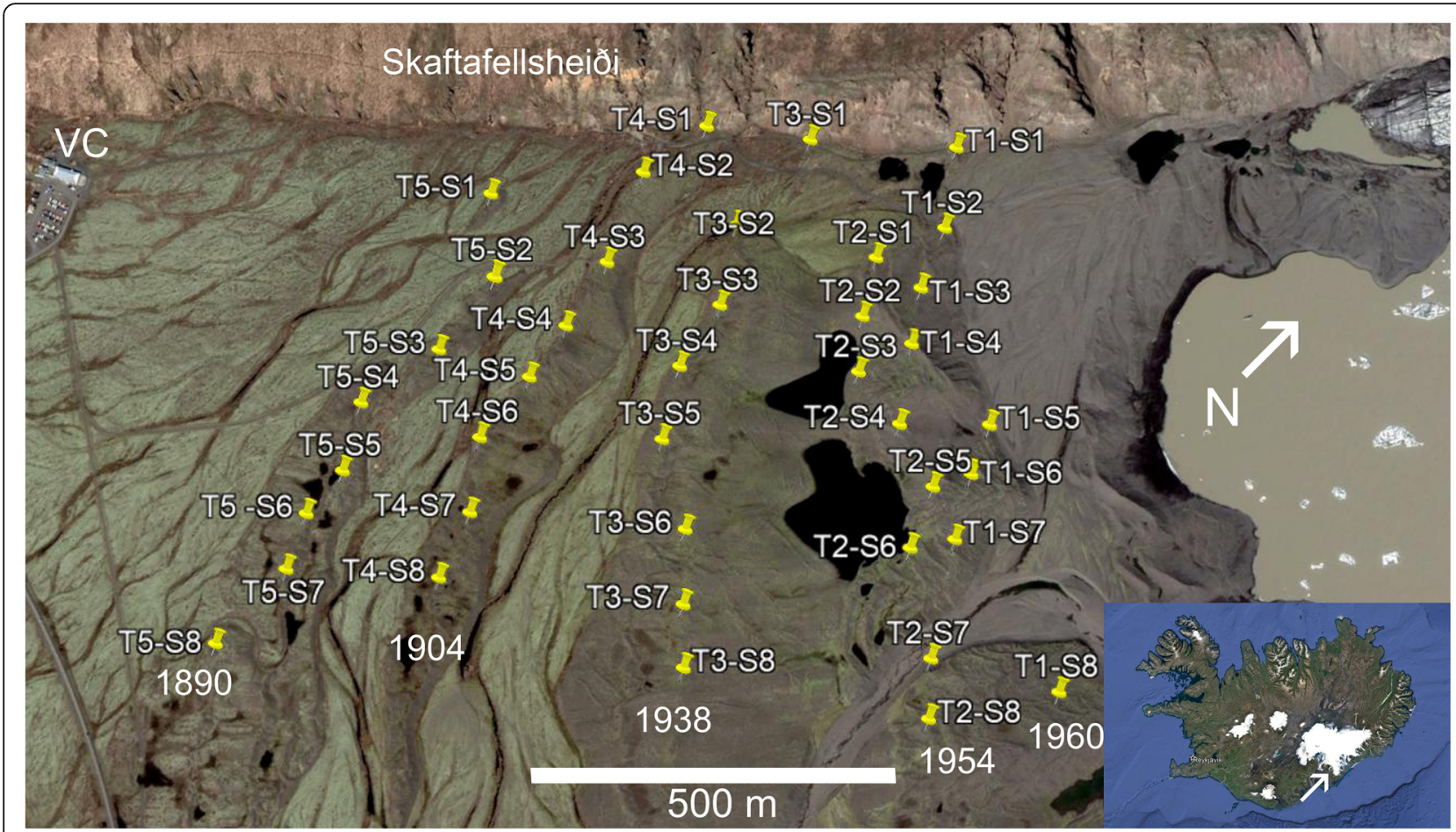

Fig. 1 Map of the Skaftafellsjökull foreland with the locations of all stations in the five transects marked. The dates represent the ages of the moraines on which each transect was located. Skaftafellsheiði is the ridge that borders the foreland to the northwest. Arrow on inset map indicates location of the field area. VC, park visitor center. The figure is adapted from data downloaded from Google Earth ${ }^{\circledR}$ (image acquisition date April 15, 2017)

1930s and into the 1940s, responding to climate warming. An interval of cooling through the 1950s and 1960s caused recession rates to slow, and some glaciers, including the Skaftafellsj kull, re-advanced in the late 1960s through 1970s. Changes in the positions of the termini of these glaciers have been and continue to be recorded by a combination of scientists and local residents and the data collected by the Hydrologic Service of the National Energy Authority (located in Reykjavik). Hence, the recessional moraines of these glaciers can be dated reasonably accurately.

At Skaftafell, in Vatnajökull National Park, the most distal moraine of the Skaftafellsjökull that is clearly identifiable is dated to the position of the ice front from 1890 to 1904 . A very pronounced topography is formed by a set of nested moraines that date from the position of the glacial front in 1938 (Fig. 1). The more proximal moraines date to the positions of the glacial front in 1954, 1960, 1982, and 2002 (Perrson 1964; Sigurðsson 2005; Hannesdóttir et al. 2014; Evans et al. 2017). Between the moraines are lower, flatter areas formed by alluvial outwash terraces with incised channels. The ages of these inter-moraine surfaces generally are poorly constrained as many of the channels are reactivated seasonally by snow melt in the spring. Nonetheless, by considering only the moraines, the foreland of the
Skaftafellsjökull forms a chronosequence, more specifically a post-incisive chronosequence (Vreeken 1975; Huggett 1998) in which distance from the ice-front corresponds approximately to the length of exposure of the surface. Thus, patterns of colonization and the direction of successional trends, i.e., conformance to the classical model, can be tested on this foreland.

The study site is located at latitude $\mathrm{N} 64^{\circ} 1.0^{\prime}$ and has a mean elevation of ca. $100 \mathrm{~m}$ asl. The southeastern coast of Iceland experiences a cool maritime climate with mean annual precipitation of approximately 1800 mm (Vilmundardóttir et al. 2014), and mean annual temperature is 4 to $6^{\circ} \mathrm{C}$, with a winter (January) mean of near $0^{\circ} \mathrm{C}$, and a summer (July) mean of $10^{\circ} \mathrm{C}$. However, air temperatures in proximity of the glacier are greatly variable and often significantly cooler than the mean. In proximity to the Skaftafellsjökull ice front, the air temperature close to ground level $($ at $5 \mathrm{~cm}$ ) has been found to decrease by as much as $9{ }^{\circ} \mathrm{C}$ compared to distal locations (Lindröth 1965). The land surface closest to the glacier is also subject to glacial winds of variable strength. Such winds are a common phenomenon formed by the high temperature gradient immediately above the glacial ice (Hoinker 1954; Geiger 1971). Prior to 1967, the study area was farmland (for sheep farming). This area was largely abandoned for grazing after 
the national park was established in 1967, and formally fenced off in 1987 (Vilmundardóttir et al. 2015).

\section{Prior work}

Glausen and Tanner (2019) studied succession on the chronosequence of the Skaftafellsj kull foreland by species counts along a series of transects parallel to the moraines. The counts were made initially in 2007 and repeated at the same locations in 2014 to examine both long-term and short-term successional species trends. This work determined that both species density and species richness increased from early to middle stages but decreased in later stages as the vegetative cover increased, largely through the increase of mosses. Colonization by the pioneer community appeared to be stochastic, but long-term succession appears directional with species replacement in middle stages and declining diversity in later stages. Species of Salix were not present on the youngest moraine, dated to 2002, but were present on the transect dated to 1982. Specimens of Betula were not observed on this transect but were found on the moraine dated to 1960 when measured in 2014; they were not observed on this moraine in 2007. Notably, the methodology for this study utilized measurements within $1 \mathrm{~m}^{2}$ quadrats spaced at $10-\mathrm{m}$ intervals along transects parallel to the moraines. The small size of the quadrats resulted in high levels of variation in species counts between sample points and consequent large standard errors for measurements summed across each transect (Tables 2 and 3; Glausen and Tanner 2019). The study described herein provides a rigorous test of the assumptions of the earlier work by expanding the area of measurement, as described below.

\section{Measurement}

We focused our study on three woody plant species that constitute most of the biomass on the foreland of the Skaftafellsjökull: Betula pubescens (Downy Birch), Salix lanata (Wooly Willow), and Salix phylicifolia (Tealeaved Willow). The patterns of colonization and propagation by these species was examined by establishing five transects, each with eight stations, on moraines of different established ages, as determined by the location of the glacial terminus at that time (Fig. 1). The transect chosen that is closest to the present position of the glacier was formed in 1960; this moraine was chosen as the youngest moraine on which both B. pubescens and Salix spp. were present in sufficient abundance to be measurable at every station. Moving away from the glacier, the older moraines used for this study were formed in 1954, 1938, 1904, and 1890, respectively. The eight sampling stations for each of the transects were positioned ca. $100 \mathrm{~m}$ apart, beginning at the point on the moraine closest to Skaftafellsheiði and following the moraine southward to southeastward toward the center of the foreland (Fig. 1). The stations were located on surfaces chosen for aspect oriented away from the glacier so that variations in sun and wind between stations were not a major factor in plant growth, although slope was variable. To reduce the effect of local variability encountered by Glausen and Tanner (2019) using $1 \mathrm{~m}^{2}$ squares, stations for this study were designed as $100-\mathrm{m}^{2}(10-\mathrm{m} \times$ 10-m) plots. A hand-held GPS unit was used to record the coordinates of each corner. The total numbers of individuals of B. pubescens and the two species of Salix within the boundaries of each station were recorded and the data converted to specimen density per square meter.

On all transects, B. pubescens displayed a tendency toward the development of patches, in contrast to $S$. lanata, which produces mainly clusters of separated individuals. For biomass calculation, the length of all stems for all three species longer than $20 \mathrm{~cm}$ was recorded. Within the patches of B. pubescens and S. phylicifolia we measured the length of all stems that appeared separated above ground level; we did not attempt to discern connections of stems below the surface. The diameters of all birches with a stem length $\geq 50 \mathrm{~cm}$ were recorded at 50 $\mathrm{cm}$ height (Snorrason and Einarsson 2006). Summary data (specimen counts and mean height for each station) for the $4000+$ measurements are presented in Table 1 . All data were collected in 2019.

\section{Data analysis}

Statistical treatments applied to the data included oneway ANOVA and multiple linear regression. To evaluate the significance of variance of the populations in the dataset, one-way ANOVA was conducted separately on both specimen density and mean size of $B$. pubescens and both Salix spp. as grouped by age and distance from Skaftafellsheiði, respectively, using the data analysis applications of Excel Microsoft $365^{\circ}$. Results were evaluated with the Shapiro-Wilk test of normality and the Brown-Forsyth test of equal variance. Multiple linear regression analyses were conducted using SigmaStat $4.0^{\circ}$, published by Systat Software, Inc., testing specimen density of B. pubescens and Salix spp. as dependent variables against the independent variables of moraine age and distance from Skaftafellsheiði. Normality of the distribution was evaluated by the Shapiro-Wilk test and constant variance evaluated by Spearman Rank Correlation. Maps of plant density for individual species were generated using the ArcGIS $10.2^{\circ}$ software.

\section{Biomass calculations}

The total biomass of the woody plant species was calculated at each station. The raw stem size data were sorted into four height classes with maximum height end points 
Table 1 Summary of data collected for this study

\begin{tabular}{|c|c|c|c|c|c|c|c|c|c|c|c|c|c|c|c|c|}
\hline \multirow[t]{2}{*}{ Species } & \multirow[t]{2}{*}{ Station } & \multicolumn{3}{|c|}{ T1 (1960) } & \multicolumn{3}{|c|}{ T2 (1954) } & \multicolumn{3}{|c|}{ T3 (1938) } & \multicolumn{3}{|l|}{ T4 (1904) } & \multicolumn{3}{|c|}{ T5 (1890) } \\
\hline & & Distance & Count & $\begin{array}{l}\text { Mean } \\
\text { size }\end{array}$ & Distance & Count & $\begin{array}{l}\text { Mean } \\
\text { size }\end{array}$ & Distance & Count & $\begin{array}{l}\text { Mean } \\
\text { size }\end{array}$ & Distance & Count & $\begin{array}{l}\text { Mean } \\
\text { size }\end{array}$ & Distance & Count & $\begin{array}{l}\text { Mean } \\
\text { size }\end{array}$ \\
\hline \multirow{8}{*}{$\begin{array}{l}\text { B. } \\
\text { pubescens }\end{array}$} & s1 & 23 & 6 & 86.7 & 194 & 101 & 66.2 & 25 & 96 & 66.9 & 29 & 263 & 39.2 & 133 & 184 & 51.1 \\
\hline & s2 & 144 & 23 & 76.3 & 282 & 117 & 54.6 & 182 & 186 & 42.8 & 98 & 211 & 38.6 & 267 & 164 & 47.3 \\
\hline & s3 & 232 & 72 & 58.8 & 373 & 87 & 57.4 & 306 & 212 & 49.7 & 239 & 158 & 42.0 & 383 & 114 & 43.9 \\
\hline & s4 & 327 & 19 & 54.2 & 455 & 49 & 0.0 & 409 & 44 & 59.8 & 342 & 174 & 46.7 & 466 & 120 & 59.5 \\
\hline & s5 & 465 & 11 & 35.5 & 555 & 63 & 69.8 & 513 & 80 & 58.0 & 417 & 138 & 53.6 & 574 & 201 & 46.1 \\
\hline & s6 & 568 & 17 & 84.4 & 640 & 26 & 60.0 & 652 & 19 & 50.0 & 513 & 142 & 50.0 & 715 & 144 & 68.1 \\
\hline & s7 & 637 & 9 & 106.7 & 821 & 133 & 67.9 & 771 & 216 & 46.9 & 635 & 215 & 48.8 & 796 & 124 & 48.6 \\
\hline & s8 & 893 & 10 & 73.0 & 913 & 78 & 62.1 & 871 & 51 & 59.8 & 740 & 146 & 52.4 & 863 & 127 & 49.3 \\
\hline \multirow[t]{8}{*}{ S. lanata } & s1 & 23 & 18 & 29.4 & 194 & 65 & 26.3 & 25 & 100 & 24.5 & 29 & 11 & 23.2 & 133 & 11 & 26.5 \\
\hline & s2 & 144 & 24 & 25.0 & 282 & 39 & 25.6 & 182 & 31 & 22.1 & 98 & 22 & 23.4 & 267 & 3 & 20.0 \\
\hline & s3 & 232 & 59 & 27.8 & 373 & 30 & 24.2 & 306 & 50 & 24.4 & 239 & 11 & 22.7 & 383 & 2 & 27.5 \\
\hline & s4 & 327 & 17 & 23.8 & 455 & 49 & 24.5 & 409 & 14 & 25.0 & 342 & 8 & 33.1 & 466 & 4 & 26.3 \\
\hline & s5 & 465 & 38 & 22.8 & 555 & 56 & 24.0 & 513 & 20 & 26.0 & 417 & 11 & 20.9 & 574 & 2 & 20.0 \\
\hline & s6 & 568 & 9 & 27.2 & 640 & 18 & 21.1 & 652 & 16 & 22.2 & 513 & 2 & 25.0 & 715 & 1 & 20.0 \\
\hline & s7 & 637 & 0 & 0.0 & 821 & 41 & 22.6 & 771 & 9 & 21.1 & 635 & 36 & 24.2 & 796 & 5 & 24.0 \\
\hline & s8 & 893 & 36 & 25.3 & 913 & 14 & 22.5 & 871 & 14 & 25.0 & 740 & 28 & 23.6 & 863 & 0 & 0.0 \\
\hline \multirow{8}{*}{$\begin{array}{l}\text { S. } \\
\text { phylicifolia }\end{array}$} & s1 & 23 & 14 & 44.3 & 194 & 16 & 28.0 & 25 & 40 & 37.1 & 29 & 16 & 25.0 & 133 & 37 & 31.8 \\
\hline & s2 & 144 & 9 & 26.7 & 282 & 0 & 0.0 & 182 & 7 & 20.7 & 98 & 14 & 28.9 & 267 & 4 & 40.0 \\
\hline & s3 & 232 & 37 & 31.1 & 373 & 28 & 23.9 & 306 & 11 & 46.8 & 239 & 5 & 28.8 & 383 & 0 & 0.0 \\
\hline & s4 & 327 & 1 & 20.0 & 455 & 17 & 52.4 & 409 & 5 & 42.0 & 342 & 26 & 35.8 & 466 & 15 & 23.0 \\
\hline & s5 & 465 & 8 & 31.3 & 555 & 4 & 23.8 & 513 & 0 & 0.0 & 417 & 0 & 0.0 & 574 & 8 & 26.3 \\
\hline & s6 & 568 & 11 & 25.9 & 640 & 44 & 20.0 & 652 & 63 & 27.8 & 513 & 4 & 46.3 & 715 & 6 & 24.2 \\
\hline & s7 & 637 & 21 & 27.6 & 821 & 8 & 28.1 & 771 & 14 & 28.9 & 635 & 27 & 29.1 & 796 & 0 & 0.0 \\
\hline & s8 & 893 & 18 & 29.7 & 913 & 2 & 25.0 & 871 & 10 & 25.0 & 740 & 25 & 31.8 & 863 & 0 & 0.0 \\
\hline
\end{tabular}

Distance $=$ meters from Skaftafellsheiði ridge measured to northeast corner of station; mean size is stem length in centimeters

of $0.5 \mathrm{~m}, 0.75 \mathrm{~m}, 1.0 \mathrm{~m}$, and $>1.0 \mathrm{~m}$ and the mean for the class used to represent the class for mass calculation. Diameter for specimens less than 0.5-m high was set at a constant $0.3 \mathrm{~cm}$. Dry weight aboveground biomass (AGB) for birch and willows was calculated from singletree empirical algorithms published by Snorrason and Einarsson (2006). For B. pubescens, $\mathrm{AGB}_{\text {birch }}=$ $0.0634 d^{2.1552} h^{0.2877}$ in kilograms, where $h=$ stem length and $d=$ diameter at $0.5 \mathrm{~m}$ height. For both $S$. lanata and S. phylicifolia, we used the algorithm developed for Salix myrsinifolia as a closest approximation, $\mathrm{AGB}_{\text {willow }}=$ $0.0348 d^{1.9123} h^{0.8904}$. The root biomass (RB) for birch was calculated using the empirical equation for B. pubescens published by Palacio et al. (2008), $\log (\mathrm{RB})=0.985 \times$ $\log (\mathrm{AGB})-0.124$. The root biomass for the willow species was approximated as $\mathrm{RB}=1.4(\mathrm{AGB})$, based on the range of ratios of root biomass to total biomass for a wide variety of willow species published by Iversen et al. (2014). The total biomass for both B. pubescens and Salix spp. was converted to biomass carbon by a conversion factor of 0.498 (Birdsey 1992), and the result total carbon mass for each $100 \mathrm{~m}^{2}$ station converted to mass $\mathrm{g} \mathrm{C} \mathrm{m}^{-2}$.

\section{Results \\ Age}

The hypothesis of age control on the populations of one or more of the studied species was tested through comparison of specimen density by moraine age. The general trends of increasing density of $B$. pubescens and decreasing density of Salix spp. with time is shown in Figs. 2 a and $b$, respectively. The data for the density of individuals for each of the three species per $\mathrm{m}^{2}$ were tested by one-way ANOVA for the significance of variance when grouped by age (Table 2). The results indicate that the variance in the population density of $B$. pubescens and $S$. lanata is significant at the level $p<0.05$, but the S. phylicifolia data does not display significant variance when grouped by sample age. Multiple linear regression analysis for the density of specimens of B. pubescens per $\mathrm{m}^{2}$ 


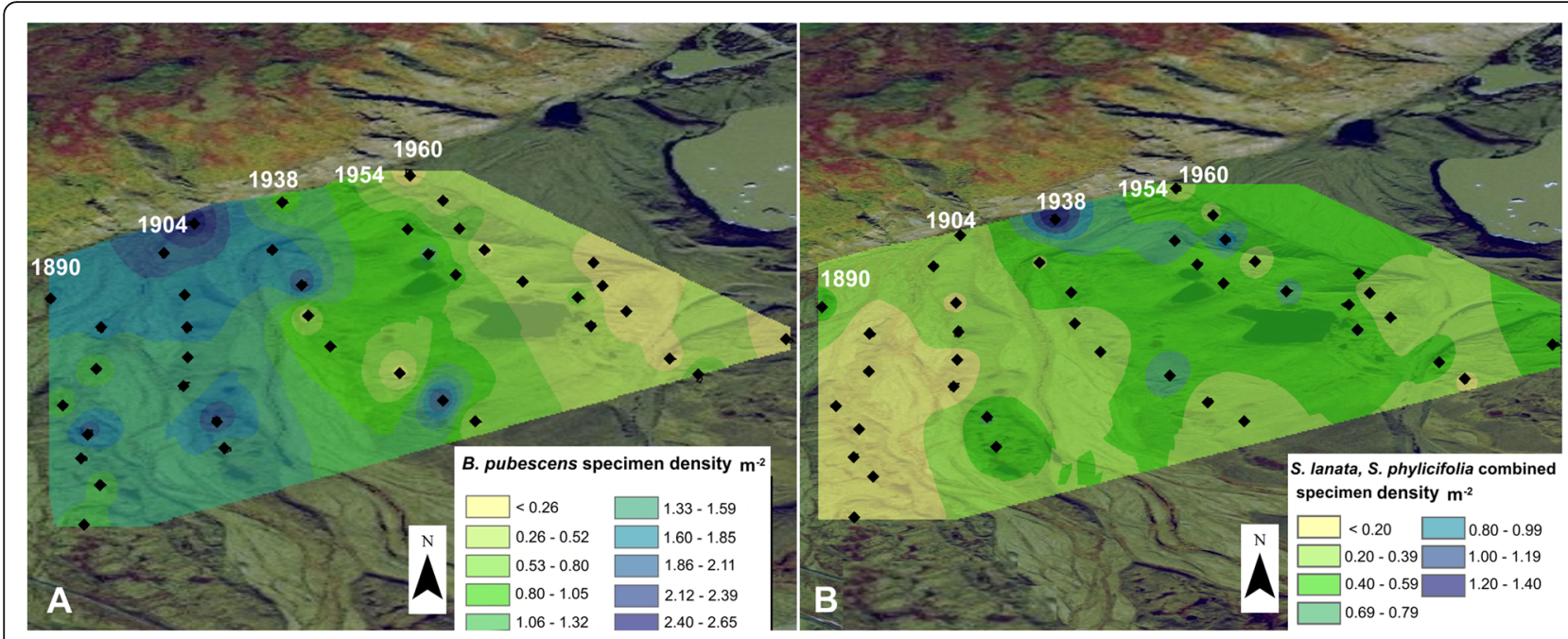

Fig. 2 Contour maps of the density of specimens of B. pubescens (a) and combined Salix spp. (b) at each station (each station = $100 \mathrm{~m}^{2}$ ), with interpolation of the density of individuals per $\mathrm{m}^{2}$ between. Maps constructed with the ArcGIS 10.2 software, based on map in Fig. 1

against the factors of moraine age and distance from Skaftafelsheiði demonstrates a relatively strong correlation $\left(r^{2}=0.503\right)$ with positive slope for the regression factor of age. Significance of the correlation at $p<0.05$ is demonstrated for age (Table 4). Among the willow species, the density of $S$. lanata specimens demonstrate a correlation with age $\left(r^{2}=0.33\right)$, but with negative regression slope for age. The strength of the correlation also is significant at $p<0.05$. S. phylicifolia specimen counts similarly demonstrate a correlation with negative regression slope for moraine age, but the correlation is not significant.

Trends for the mean size of the specimens varying according to the age of moraine are less apparent than the trends for specimen density. Analysis by ANOVA of the data for specimen size for the three species grouped by age demonstrated variance at a level of significance for B. pubescens, but not for either species of Salix (Table 3). Multiple linear regression analysis of the mean size data for B. pubescens, again with moraine age and distance from Skaftafelsheiði as the

Table 2 One-way ANOVA results analyzing variance in specimen density data of $B$. pubescens, S. lanata, and S. phylicifolia grouped by age of the moraines and by distance from Skaftafelsheiði, respectively

\begin{tabular}{llll}
\hline & Species & $\boldsymbol{F}$ statistic & $\boldsymbol{P}$ value \\
\hline Age & B. pubescens & 13.62 & $<0.001$ \\
& S. lanata & 4.39 & 0.006 \\
\multirow{2}{*}{ Distance } & S. phylicifolia & 0.48 & 0.754 \\
& B. pubescens & 0.79 & 0.601 \\
& S. lanata & 0.97 & 0.469 \\
& S. phylicifolia & 1.60 & 0.172 \\
\hline
\end{tabular}

independent variables, demonstrates a correlation $\left(r^{2}=\right.$ 0.242) with negative regression slope for age and significance at $p<0.05$. Both S. lanata and S. phylicifolia displayed a negative regression slope for age, but neither species correlated size with age at a level of significance.

\section{Distance from Skaftafellsheiði}

The collected data allow us to examine the influence of the proximity of the sampling stations to Skaftafellsheiði on the density and size of individual specimens for all three species. Systematic variations in specimen density as a function of distance from the ridge are less distinct than are the variations by age (Fig. 2). One-way ANOVA of the specimen density for all three species failed to demonstrate significant differences in variance when the data were grouped by distance (Table 2). Similarly, when the data for the mean size of all three species were grouped by distance and tested, no differences in variance of statistical significance were observed for any of the species (Table 3). The multiple linear regression analyses described above included distance as an

Table 3 One-way ANOVA results analyzing variance in data for mean size of B. pubescens, S. lanata, and S. phylicifolia grouped by age of the moraines where measured and by distance from Skaftafelsheiði, respectively

\begin{tabular}{llll}
\hline & Species & $\boldsymbol{F}$ statistic & $\boldsymbol{P}$ value \\
\hline Age & B. pubescens & 3.16 & 0.026 \\
& S. lanata & 0.19 & 0.943 \\
\multirow{3}{*}{ Distance } & S. phylicifolia & 0.97 & 0.442 \\
& B. pubescens & 0.86 & 0.548 \\
& S. lanata & 1.82 & 0.117 \\
& S. phylicifolia & 1.60 & 0.172 \\
\hline
\end{tabular}


Table 4 Multiple linear regression analysis results testing data for density of specimens per $\mathrm{m}^{2}$ against the factors of moraine age and distance from Skaftafelsheiði for B. pubescens and both Salix species

\begin{tabular}{lllc}
\hline Species & $\boldsymbol{R}$ squared & $\boldsymbol{P}$ value & Slope \\
\hline B. pubescens & 0.503 & & + \\
Age & & $<0.001$ & - \\
Distance & & 0.115 & - \\
S. lanata & 0.333 & & - \\
Age & & $<0.001$ & - \\
Distance & & 0.038 & - \\
S. phylicifolia & 0.032 & & - \\
Age & & 0.386 & - \\
Distance & & 0.520 & \\
\hline
\end{tabular}

independent variable. All three species exhibited a negative slope of regression for the specimen density when tested against distance, with only $S$. lanata correlating at a level of significance $p<0.05$ (Table 4). Testing mean specimen size data for all species against distance found that $S$. lanata again was the only species with a correlation at a level of significance $p<0.05$ (Table 5). The slopes of the regressions for both Salix species were negative, with only $B$. pubescens exhibiting a positive slope, but not at a level of significance.

\section{Biomass carbon}

Utilizing the methods described above, we calculated the carbon mass contained in the aboveground woody biomass of B. pubescens and Salix spp. plus their respective estimated root masses to find the woody biomass for each station. This figure was converted to carbon mass, and the mean for each moraine calculated from the eight stations. This is presented in Table 6 as $\mathrm{g} \mathrm{C} \mathrm{m}^{-2}$. Total

Table 5 Multiple linear regression analysis results testing data for size of specimens against factors of moraine age and distance from Skaftafelsheiði for B. pubescens and both Salix species

\begin{tabular}{llll}
\hline Species & $\boldsymbol{R}$ squared & $\boldsymbol{P}$ value & Slope \\
\hline $\begin{array}{l}\text { B. pubescens } \\
\text { Age }\end{array}$ & 0.242 & & - \\
$\quad$ & & 0.002 & + \\
Distance & 0.134 & 0.576 & - \\
S. lanata & & 0.552 & - \\
$\quad$ Age & & 0.026 & - \\
Distance & 0.094 & & - \\
S. phylicifolia & & 0.211 & - \\
Age & & 0.146 & - \\
Distance & & & \\
\hline
\end{tabular}

The slope of the correlation of individual factors is the sign of the term in the regression equation woody biomass increased from $7.15 \mathrm{~g} \mathrm{C} \mathrm{m}^{-2}$ on transect 1 to a maximum of $28.53 \mathrm{~g} \mathrm{C} \mathrm{m}^{-2}\left(=2.6 \mathrm{t} \mathrm{C} \mathrm{ha}^{-1}\right)$ on transect 5 . The overall rate of biomass carbon accretion over the 129 year age of the chronosequence is $0.22 \mathrm{~g} \mathrm{C}$ $\mathrm{m}^{-2}$, but most of the increase occurred in the brief $(6$ years) interval between transect 1 and transect $2(22.12 \mathrm{~g}$ $\mathrm{C} \mathrm{m}^{-2}$ ), corresponding to an accretion rate of $2.5 \mathrm{~g} \mathrm{C}$ $\mathrm{m}^{-2} \mathrm{y}^{-1}$. This increase coincided with a four-fold increase in the density of specimens of $B$. pubescens. Biomass carbon continued to increase on transect 3 (25.73 g $\left.\mathrm{C} \mathrm{m}^{-2}\right)$, but declined slightly on transect $4(22.48 \mathrm{~g} \mathrm{C}$ $\mathrm{m}^{-2}$ ) before increasing to transect 5 .

\section{Discussion \\ Colonization controls}

This study attempts to clarify the spatio-temporal model of succession that controls floral colonization and growth on the moraines of the Skaftafellsj kull through study of the colonization and propagation of the woody species, B. pubescens, S. lanata, and S. phylicifolia. Additionally, the data collected in this study permit us to examine the rate of biomass accretion to the landscape by these species. In considering the initial colonization of the foreland, we note that Glausen and Tanner (2019) found both B. pubescens and Salix spp. to be absent on the youngest moraine they examined (from 2002); the earliest pioneer species were primarily Racomitrium mosses, graminoids, and low heath shrubs. Both species of Salix were found on the 1982 moraine in that study. B. pubescens was absent on this moraine when measured in 2007 but had appeared by 2014. Clearly, Salix spp. are the more successful pioneer species on these moraines. Despite this early success, however, the number of individuals of $B$. pubescens outnumbers those of the two Salix species combined on all but the youngest moraine (transect 1) as B. pubescens density increased consistently over time, in contrast to the Salix spp. The biomass contained therein displays the same relationship. Below, we explore possible reasons for the order of colonization and temporal changes in species distribution.

On the nearby Skeiđarársandur, the broad outwash plain of the Skeiđarárj kull adjacent to the Skaftafellsjökull foreland a few kilometers to the west, Marteinsdóttir et al. (2010, 2013) concluded that early succession was mainly stochastic in general, but subject to environmental filters, such as seed mortality and emergence rate. Mori et al. (2013), in contrast, studied colonization on Ellesmere Island (Canada) and found colonization to be mainly non-stochastic, with the distribution of pioneer species determined by the availability of favorable microsites created by depressions and boulders that provide shelter from wind desiccation. The distribution of these favorable sites may be random in this setting, but 
Table 6 Total biomass (AGB plus RB) by species for each station and transect, reported as $\mathrm{g} \mathrm{C} \mathrm{m}^{-2}$

\begin{tabular}{|c|c|c|c|c|c|c|c|c|c|c|}
\hline Transect & & $s 1$ & s2 & s3 & s4 & s5 & s6 & s7 & s8 & Transect mean \\
\hline \multirow[t]{3}{*}{$\mathrm{T} 1$} & B. pubescens & 1.59 & 3.61 & 6.97 & 1.23 & 1.99 & 4.47 & 15.18 & 7.01 & \\
\hline & Salix spp. & 2.13 & 1.34 & 4.92 & 0.73 & 1.87 & 0.81 & 0.95 & 2.38 & \\
\hline & Station total & 3.72 & 4.95 & 11.89 & 1.96 & 3.86 & 5.28 & 16.13 & 9.39 & 7.15 \\
\hline \multirow[t]{3}{*}{$\mathrm{T} 2$} & B. pubescens & 22.79 & 12.32 & 22.02 & 0.00 & 37.76 & 3.96 & 38.74 & 21.28 & \\
\hline & Salix spp. & 3.25 & 1.58 & 2.36 & 3.42 & 2.44 & 2.52 & 1.99 & 0.55 & \\
\hline & Station total & 26.04 & 13.90 & 24.38 & 3.42 & 40.20 & 6.48 & 40.73 & 21.83 & 22.12 \\
\hline \multirow[t]{3}{*}{ T3 } & B. pubescens & 80.58 & 12.01 & 41.26 & 6.13 & 14.79 & 1.38 & 20.96 & 10.77 & \\
\hline & Salix spp. & 6.52 & 1.54 & 2.94 & 0.86 & 0.81 & 3.39 & 0.93 & 0.97 & \\
\hline & Station total & 87.10 & 13.55 & 44.20 & 6.99 & 15.60 & 4.77 & 21.89 & 11.74 & 25.73 \\
\hline \multirow[t]{3}{*}{ T4 } & B. pubesens & 14.31 & 11.86 & 9.65 & 27.39 & 16.06 & 17.72 & 43.61 & 28.45 & \\
\hline & Salix spp. & 1.10 & 1.42 & 0.61 & 1.98 & 0.45 & 0.43 & 2.56 & 2.25 & \\
\hline & Station total & 15.41 & 13.28 & 10.26 & 29.37 & 16.51 & 18.15 & 46.17 & 30.70 & 22.48 \\
\hline \multirow[t]{3}{*}{ T5 } & B. pubescens & 29.20 & 24.28 & 14.77 & 43.14 & 13.19 & 48.24 & 28.46 & 21.97 & \\
\hline & Salix spp. & 2.19 & 0.38 & 0.81 & 0.77 & 0.41 & 0.28 & 0.20 & 0.00 & \\
\hline & Station total & 31.39 & 24.66 & 15.58 & 43.91 & 13.60 & 48.52 & 28.66 & 21.97 & 28.54 \\
\hline
\end{tabular}

colonization is deterministic in this interpretation and not subject to seed limitation.

Of particular relevance to our study, we note Whittaker's (1993) study of the foreland of the Storbreen Glacier (Norway) foreland in which the author concluded that colonization by Salix spp. (Salix glauca and S. lanata) is not environmentally constrained. These species colonize early, preferring wet ground, and build up quickly, attaining a high frequency in under 50 years. The author concluded that colonization by Salix spp. was largely dependent on propagule supply. The author noted further that Betula nana, in contrast, was much slower to colonize, perhaps responding to an environmental filter; specifically, it was suggested that $B$. nana colonization responds to ecosystem development. Whittaker noted further that B. nana distribution was patchy, particularly on the older parts of the chronosequence, similar to our observations of B. pubescens at Skaftafell. Burga et al. (2010), in their study of succession on the foreland of the Morteratsch Glacier (Switzerland), noted similar dynamics of colonization between Salix spp. and B. nana, but also found that both were rare or absent on areas of the foreland more than 100 years old.

Vilmundardóttir et al. (2014) documented that both soil carbon and nitrogen increased with age across the Skaftafellsj kull foreland chronosequence. Organic carbon in the top $10 \mathrm{~cm}$ of the soil increased from $0.05 \%$ on the youngest moraines $(<10$ years old at the time of their measurement) to $0.30 \%$ at 30 years, to $1.77 \%$ on the oldest moraine. Similarly, soil nitrogen increased from a low of $0.004 \%$ on the youngest moraine to $0.101 \%$ on the oldest moraine. In their study, total vegetative cover increased from a low of $6.2 \%$ on the youngest moraine, to $61.3 \%$ at 65 years, and $66.7 \%$ on the oldest terrain. The results of Glausen and Tanner (2019) were similar, with the vegetative cover on the oldest moraine measured at $66.2 \%$ in 2007 , but this value increased to $93.8 \%$ when remeasured in 2014. The study by Glaussen and Tanner found that species richness, including forbs and graminoids, generally peaked in mid-succession and declined in late stages. Most of the increase in vegetative cover resulted from the increase in bryophyte cover.

The data presented here, and from the previous studies of Vilmundardóttir et al. (2014) and Glausen and Tanner (2019), demonstrate that Salix spp. are relatively unconstrained by environmental conditions, displaying no preference for protected seeding sites, and thus are a particularly effective pioneer species. $B$. pubescens, in contrast, is subject to one or more environmental filters that restrict colonization despite the availability of propagules from Skaftafellsheiði, mirroring the observations of Whittaker (1993) and Burga et al. (2010). We suggest here that soil properties, e.g., low nitrogen content, restrict the viability of Betula propagules on young moraines. Improvement of the soil properties during primary succession increased the rate of successful seeding on progressively older moraines. Hence, success of $B$. pubescens is dependent on facilitation by other species. However, the overall increase in vegetative cover by mosses and low heath shrubs (documented by Glausen and Tanner 2019) that facilitates the spread of B. pubescens may suppress the growth of Salix by eliminating potential seeding sites. Thus, a successional pattern of declining species richness through loss of pioneer species appears to be in effect on the Skaftafellsjökull 
foreland. The growth of $B$. pubescens, in contrast, is promoted by increased nutrient availability on the older portions of the foreland and successful competition for seeding sites. Another potential reason for the success of $B$. pubescens is its propensity to grow in dense patches that facilitate propagation.

\section{Proximity to propagule source}

One hypothesis tested in this study is that distance from the Skaftafellsheiði ridge, as a potential reservoir of propagules for $B$. pubescens, exerts control on the number of individuals on the moraines. Indeed, the proximity to a propagule source could readily explain the comparative success of this species, as compared to Salix spp. If the hypothesis is correct, the number of $B$. pubescens should decrease consistently with distance from the ridge, while the numbers of individuals of Salix spp., lacking a similar propagule source, would remain relatively constant. The data presented above demonstrate a general inverse correlation of $B$. pubescens individuals with distance from the ridge, but the correlations did not reach a level of statistical significance $(p \geq 0.05)$. Both S. lanata and S. phylicifolia density correlate with distance from Skaftafelsheiði with negative slope, but only the $S$. lanata correlation is statistically significant. If proximity to the propagule source was a major control on colonization of $B$. pubescens, the inverse correlation of specimen density vs. distance should be much stronger for B. pubescens than for Salix spp. As this is not the case, the hypothesis is unproven.

We suggest alternatively that the inverse correlations we observe for B. pubescens and both species of Salix, although marginal, are related to one or more environmental factors that vary by position on the foreland. The Skaftafellsheiði ridge may play an indirect role in colonization by providing a more sheltered environment for seeding at proximal sites whereas more distal sites on each transect have more exposure to wind and sun than the proximal sites. The soils of the glacial moraines are coarse-grained, poorly sorted, and well-drained and so have overall low moisture retention. The seeding sites with higher exposure to wind and sun are likely to have lower levels of soil moisture than sites closer to the ridge, which may inhibit successful seeding. Thus, proximity to the ridge may be a factor in colonization by all woody species on the Skaftefellsjökull foreland, but not due to proximity of a propagule source, as hypothesized. We note anecdotally that $B$. pubescens grows abundantly and robustly in the alluvial channels between the moraines where they are closer to the water table.

\section{Successional model}

Previous study of primary succession on the Skaftafellsjökull foreland (Glausen and Tanner 2019) suggested that succession was proceeding in a classical model sense, with homogenization documented by increasing species richness and diversity in middle stages and declines in both richness and diversity in later stages (Yarranton and Morrison 1974; Holdaway and Sparrow 2006). We note here that our observations are consistent with the earlier conclusions, although with an addendum; homogenization, as predicted in the classical model applies to the moraines. The entire landscape, however, is better described by the geoecological model (Matthews 1992; Bertness and Callaway 1994; Tirado and Pugnaire 2005). As described above, alluvial channels occur between the moraines. Within these channels are stream beds incised into glacial outwash deposits in which B. pubescens grow densely and robustly, presumably promoted by the proximity to the water table. The lines of trees filling the sinuous stream bed are clearly visible in satellite view (Fig. 1). Thus, a topographic/edaphic gradient exists on the foreland at the landscape level that separates the moraines from the alluvial outwash terraces and channels.

\section{Biomass accretion}

The results above demonstrate a general trend of biomass increase with time. Because the total biomass measurement is the composite of the individual species, the differing age trends in the density of individuals of the three species affect the overall rate of change. The largest biomass increase occurred during early succession across an interval of only 6 years between transects 1 and 2, corresponding to a major increase in the numbers for all species. The biomass change and corresponding increase in specimen numbers is not as pronounced from transect 2 to transect 3 . Biomass decreased from transect 3 to transect 4 ; here, we note that although the density of $B$. pubescens specimens increased in number from transect 3 to transect 4 , the mean size remained constant or decreased at every other station in the transect. Transect 4 also marked a very pronounced decline in the density of Salix individuals compared to transect 3. The increase in biomass from transect 4 to transect 5 , which has the highest biomass, corresponds to the continued increase in $B$. pubescens density, offsetting the decrease in Salix spp.

\section{Conclusions}

We collected data on the number and size of three woody species on the Skaftafellsjökull foreland chronosequence to examine their spatial and temporal dynamics during succession. The data demonstrate that colonization of the landscape by Salix spp. is largely stochastic and precedes the appearance of $B$. pubescens. We suggest that colonization of $B$. pubescens occurs later due to environmental filters, most likely including 
nutrient availability. All three species increase in density rapidly in early to middle successional stages, corresponding to rapid biomass increase. Later stages are marked by the decrease in the density of Salix spp. individuals while $B$. pubescens continued to increase. We suggest that the decline of Salix spp. over time was related to increased vegetative cover in later successional stages, largely due to the increase in bryophytes, and competition for seeding sites among B. pubescens, Salix spp., and other community members. Thus, environmental pressures generated by classical primary succession control the temporal distribution of individual species.

The forested ridge Skaftafellsheiði has the potential to serve as a source of propagules for $B$. pubescens, but statistical evidence for this is lacking. Comparison of the number of individuals of all three species to distance from the ridge indicates weak inverse correlations that are mostly not statistically significant. Other environmental factors may explain declines in the numbers of individuals with distance from the ridge. Specifically, distal locations have greater exposure to wind and sun which may cause lower soil moisture and hinder successful seeding.

\section{Abbreviations}

ABG: Aboveground biomass; ANOVA: Analysis of variance; GPS: Global positioning system; PCA: Principal component analysis; RB: Root biomass

\section{Acknowledgements}

Permission to conduct this study was granted generously by H. Árnadóttir, director of the Vatnajökull National Park in 2019. This manuscript was greatly improved by the thoughtful comments of N. Balster and an anonymous reviewer.

\section{Authors' contributions}

LHT designed the project. Data collection and analyses were conducted primarily by HES and MAM. LHT was responsible for much of the manuscript with input and editing by HES and MAM. The authors read and approved the final manuscript.

\section{Funding}

The collection of the data herein was supported by Le Moyne College through the Joseph C. Georg Endowed Professorship, awarded to LHT. Analysis of the data and work on the manuscript were supported by McDevitt Center for Excellence fellowships awarded to HES and MAM.

\section{Availability of data and materials}

The raw data used to support the findings of this study are available in xlsx format from the corresponding author upon request.

\section{Ethics approval and consent to participate}

Not applicable.

\section{Consent for publication}

Not applicable

\section{Competing interests}

The authors declare that there are no competing interests regarding the publication of this paper.
Received: 25 August 2020 Accepted: 20 January 2021

Published online: 05 February 2021

\section{References}

Bertness MD, Callaway R (1994) Positive interactions in communities. Trends Ecol Evol 9:191-193

Birdsey RA (1992) Carbon storage and accumulation in United States forest ecosystems. US Dept Agr For Serv Gen Tech Rep WO-59

Burga CA, Krüsi B, Egli M, Wernli M, Elsener S, Ziefle M, Fischer T, Mavris C (2010) Plant succession and soil development on the foreland of the Morteratsch glacier (Pontresina, Switzerland): straight forward or chaotic? Flora 205:561576

Butters FK (1914) Some peculiar causes of plant distribution in the Selkirk Mountains, British Columbia. Minnesota Botan Stud 4:313-331

Cooper WS (1916) Plant succession in the Mount Robson region, British Columbia. Plant World 19:211-238

Cooper WS (1931) A third expedition to Glacier Bay, Alaska. Ecology 12:61-95

Cutler NA, Belyea LR, Dugmore AJ (2008) The spatiotemporal dynamics of a primary succession. J Ecol 96:231-246

del Moral R (1998) Early succession on lahars spawned by Mount St. Helens. Am J Bot 85:820-828

del Moral R (1999) Plant succession on pumice at Mount St. Helens, Washington. Am Midland Nat 141:101-114

Dowdeswell JA (1995) Glaciers in the high Arctic and recent environmental change. Phil Trans Royal Soc London Ser A 352:321-334

Evans DJA, Ewertowski M, Orton C (2017) Skaftafellsjöokull, Iceland: glacial geomorphology recording glacier recession since the Little Ice Age. J Maps 13(2):358-368

Fægri K (1933) Über die längenvariationen einiger Gletscher des Jostedalsbre und die dadurch bedingten pflanzensukzessionen. Bergens Museum Årbok 1933. Naturvidenskapelig rekke 7:1-255

Fickert T (2017) Glacier forelands - unique field laboratories for the study of primary succession of plants. In: Godone D (ed) Glaciers - evolution in a changing world. InTech Open, London. https://doi.org/10.5772/intechopen. 69479

Fickert T (2020) Common patterns and diverging trajectories in primary succession of plants in Eastern Alpine glacier forelands. Diversity 12:191. https://doi.org/10.3390/d12050191

Friedel H (1934) Boden- und vegetationsentwiklung um pasterzenufer. Carinthia 2:29-41

Friedel H (1937) Boden- und vegetationsentwiklung im vorfelde des Rhonegletschers. Vorläufiger bericht. Berichtüber das Geobotanische Forschungsinstitutt Rübel in Zurich, 65-76

Friedel H (1938) Die pflanzenbesiedlung im vorfeld des Hintereisferners. Zeitschrift für Gletscherkunde 26:215-239

Garibotti IA, Pissolito Cl, Villalba R (2011) Spatiotemporal pattern of primary succession in relation to meso-topographic gradients on recently deglaciated terrains in the Patagonian Andes. Arctic Antarct Alp Res 43:555567

Geiger R (1971) The climate near the ground. Harvard University Press, Cambridge

Glausen TG, Tanner LH (2019) Successional trends and processes on a glacial foreland in Southern Iceland studied by repeated species counts. Ecol Process 8:11. https://doi.org/10.1186/s13717-019-0165-9

Hannesdóttir H, Björnsson H, Pálsson F, Aðalgeirsdóttir G, Guðrmundsson SV (2014) Area, volume and mass changes of southeast Vatnajökull ice cap, Iceland, from the Little Ice Age maximum in the late 19th century to 2010. Cryosph Discuss 8:1-55

Hodkinson ID, Coulson SJ, Webb NR (2003) Community assembly along proglacial chronosequences in the high Arctic: vegetation and soil development in north-west Svalbard. J Ecol 91:651-663

Hoinker H (1954) Beitrígezurkennte des gletscherwindes. Arch Meteorol Geophys Bioklimatol Ser B 6:36-53

Holdaway RJ, Sparrow AD (2006) Assembly rules operating along a primary riverbed-grassland successional sequence. J Ecol 94:1092-1102

Holling CS (1992) Cross-scale morphology, geometry, and dynamics of ecosystems. Ecol Monogr 62:447-502

Huggett RJ (1998) Soil chronosequences, soil development, and soil evolution: a critical review. Catena 32:155-172

IPCC (2014) Climate change 2014: synthesis report. Contribution of working groups I, II and III to the Fifth Assessment Report of the Intergovernmental 
Panel on Climate Change. Core Writing Team, Pachauri RK, Meyer LA (eds). IPCC, Geneva

IPCC (2019) IPCC special report on the ocean and cryosphere in a changing climate. H.-O. Pörtner, D.C. Roberts, V. Masson-Delmotte, P. Zhai, M. Tignor, E. Poloczanska, K. Mintenbeck, A. Alegría, M. Nicolai, A. Okem, J. Petzold, B. Rama, N.M. Weyer (eds). IPCC, Geneva

Iversen CM, Sloan VL, Sullivan PF, Euskirchen ES, McGuire AD, Norby RJ, Walker AP, Warren JM, Wullschleger SD (2014) The unseen iceberg: plant roots in arctic tundra. New Phytol 205:34-58

Jägerbrand AK, Kudo G, Alatalo JM, Molau U (2012) Effects of neighboring vascular plants on the abundance of bryophytes in different vegetation types. Polar Sci 6:200-208

Jones GA, Henry GHR (2003) Primary plant succession on recently deglaciated terrain in the Canadian High Arctic. J Biogeograph 30:277-296

Lefauconnier B, Hagen JO, Orbaeck JB, Melvold K, Isaksson E (1999) Glacier balance trends in the Kongsfjorden area, western Spitsbergen, Svalbard, in relation to the climate. Polar Res 18:307-313

Liengen T (1999) Environmental factors influencing the nitrogen fixation activity of free-living cyanobacteria from a high arctic area, Spitsbergen. Can J Microbiol 45:573-581

Liengen T, Olsen RA (1997) Seasonal and site-specific variations in nitrogen fixation in a high arctic area, Ny-Ålesund, Spitsbergen. Can J Microbiol 43: 759-769

Liestøl O (1988) The glaciers in the Kongsfjorden area, Spitsbergen. Norsk Geografisk Tidsskrift 42:231-238

Lindröth CH (1965) Skaftafell, Iceland: a living glacial refugium. Oikos Supplement 6:1-142

Lüdi W (1921) Die pflanzengesellschaften des lauterbrunnentalles und ihre sukzession. Beitr Geobotanischen Landesaufnahme 9:1-364

Lüdi W (1958) Beobachtungenüber die Besiedlung von gletschervorfeldern in den Schweizeralpen. Flora 146:386-407

Marteinsdóttir B, Svavarsdóttir K, Thórhallsdóttir TE (2010) Development of vegetation patterns in early primary succession. J Veg Sci 21:531-540

Marteinsdóttir B, Thórhallsdóttir TE, Svavarsdóttir K (2013) An experimental test of the relationship between small scale topography and seedling establishment in primary succession. Plant Ecol 214:1007-1015

Matthews JA (1992) The ecology of recently deglaciated terrain: a geoecological approach to glacier forelands and primary succession. Cambridge University Press, New York

Matthews JA, Whittaker RJ (1987) Vegetation succession on the Storbreen glacier foreland, Jotunheimen, Norway: a review. Arctic Alp Res 19:385-395

Mori AS, Uchida M, Kanda H (2013) Non-stochastic colonization by pioneer plants after deglaciation in a polar oasis of the Canadian High Arctic. Polar Sci 7: 278-287

Negri G (1934) La vegetazione delle morene del Ghiacciaio del Lys (Monte Rosa). Bolletino Comitato Glaciologico Italiano (Roma) 14:105-172

Negri G (1936) Osservazioni di U. Monterin su alcuni casi di invasione della morene gallegianti dei Ghiacciai del Monte Rosa da parte della vegetazione (contav. XVII e XVIII) Nuovo Giorniale Botanico Italiano (Firenze) 42:699-712.

Palacio S, Hester AJ, Maestro M, Millard P (2008) Browsed Betula pubescens trees are not carbon-limited. Funct Ecol 22:808-815

Perrson $\AA$ (1964) The vegetation at the margin of the receding glacier Skaftafellsjökull, southeastern Iceland. Botaniska Notiser 117:323-354

Sigurðsson O (2005) Glacier variations in Iceland 1930-1960, 1960-1990 og 20032004. Jökull 55:163-170

Snorrason A, Einarsson SF (2006) Single-tree biomass and stem volume functions for eleven tree species used in Icelandic forestry. Icel Agric Sci 19:15-24

Starfield AM, Chapin FS III (1996) Model of transient changes in Arctic and boreal vegetation in response to climate and land use change. Ecol Appl 6:842-864

Tirado R, Pugnaire Fl (2005) Community structure and positive interactions in constraining environments. Oikos 111:437-444

Vilmundardóttir OK, Gísladóttir G, Lal R (2014) Early stage development of selected soil properties along the proglacial moraines of Skaftafellsjökull glacier, SE-Iceland. Catena 121:142-150

Vilmundardóttir OK, Gísladóttir G, Lal R (2015) Soil carbon accretion along an age chronosequence formed by the retreat of the Skaftafellsjökull glacier, SEIceland. Geomorphol 228:124-133

Vreeken WJ (1975) Principal kinds of chronosequences and their significance in soil history. J Soil Sci 26:378-394

Whittaker RJ (1993) Plant population patterns in a glacier foreland succession: pioneer herbs and later-colonizing shrubs. Ecography 16:117-136
Wu I, Loucks OL (1995) From balance of nature to hierarchical patch dynamics: a paradigm shift in ecology. Quart Rev Biol 70:439-466

Yarranton GA, Morrison RG (1974) Spatial dynamics of primary succession: nucleation. J Ecol 59:417-428

\section{Publisher's Note}

Springer Nature remains neutral with regard to jurisdictional claims in published maps and institutional affiliations.

\section{Submit your manuscript to a SpringerOpen ${ }^{\circ}$ journal and benefit from:}

- Convenient online submission

- Rigorous peer review

- Open access: articles freely available online

High visibility within the field

- Retaining the copyright to your article

Submit your next manuscript at $\boldsymbol{\nabla}$ springeropen.com 